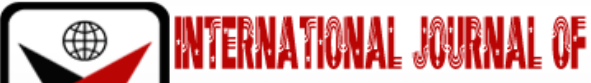

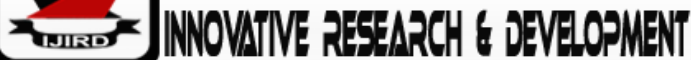

ISSN 2278-0211 (Online)

\section{Speech Acts as a Tool of Change in Religious Complimentary Messages of Selected Pentecostal Churches}

\author{
Adebola. Sarah 0. Michael \\ Principal Lecturer, Department of General Studies, \\ The Federal Polytechnic, Ede Ede, Osun Stae, Nigeria
}

\begin{abstract}
:
This work examined the way language operates in the domain of religious discourse. The way and manner in which language was manipulated to produce impact by notable clerics in their messages was examined. This study set out to investigate the types of speech acts that characterize the language of religious complimentary messages. The research applied the speech acts theory by Searle, 1969 as the theoretical framework. The data for the analysis comprised of the complimentary messages by four (4) general overseers of four (4) churches, namely: The Redeemed Christian Church, The Living Faith Church AKA Winners Church and The Living spring Chapel International. The study discovered that commissives dominated the texts as the messages were characterised by predictions, prophecies and promises to give hope and anticipation for better things. This is followed by the representatives in the degree of occurrence because it is used to give background information and explanation with the use of sub acts of stating, informing, reporting, affirming etc. This is followed by the expressive, declarations and directives respectively The study concluded that the clerics have skilfully manipulated linguistic and rhetorical resources to pass messages to the people and to assure and motivate them to a change of lifestyle and better way of life in the society.
\end{abstract}

Keywords: Pentecostal, commissives, representatives, expressives, declaratives and directives

\section{Introduction}

In most parts of the world, friends, relations and loved ones send complimentary messages- which could be in the form of cards, notes etc. - to one another on important occasions such as birthdays, graduations, Christmas or New Year, Eid-el Fitri celebrations. In most of these messages, the addressees are often showered with encomiums in recognition of their achievements. Good wishes are also expressed towards future successes of the addressees from the senders. In recent times in Nigeria, it has been noted that certain notable clerics use complimentary messages to convey their good wishes and to express their sentiments to their congregation on the occasion of the New Year festivities. Many of these, rather than being limited to encomiums, show a deviation from the normal pattern to include supplications, prophecies and certain themes for the New Year. These messages, sent out to their members are expected to perform certain functions in their lives because the production of an utterance is meant to bring about certain changes in the behaviour of the listeners. It is for this reason that writers write; preachers preach; employers, parents and teachers scold; propagandists send out news releases; statesmen give addresses.

According to Austin (1962:98) the sense in which to say something may be to do something. The uttering of certain words by appropriate people in appropriate circumstances can constitute the performing of certain conventional acts. Religious messages whether in books, sermons or compliments are meant to do certain things also. Religious discourses are issued in order to persuade, motivate, encourage, inform, correct and to bring about changes in the behaviour of the listeners or readers thus it serves as an agent of transformation in the lives of people. Quite a large number of works have been carried out on Compliments in the area of pragmatics (Manes; 1983, Manes and Wolfson, 1980; Wolfson, 1981, 1983; and Manes Wolfson and Manes, 1980) but not much has been done in the area of speech acts and religious compliments. This study thus set out to investigate the types of speech acts that characterize the language of religious complimentary messages since according to Holmes (1988) a speech act is that which explicitly or implicitly attribute credit to someone other than the speaker, usually the person addressed, for some good and that is the case with complimentary messages. It therefore opens an interesting area for research work.

\section{Methodology}

The research methodology adopted for this study is the non-experimental approach since the study is not based on the acquisition of scientific knowledge. The study population was notable Pentecostal churches in Lagos State. The primary sources of data for the study were texts already in print. These are the teachings and messages from the pastors. A random sampling technique was employed in this study and data were randomly selected from members/ church offices 
such as The Redeemed Christian Church, The Living Faith Church aka Winners Church, The Living Waters ministries AKA Grace Family Church and The Livingspring Chapel International.

\section{Language and Religion}

Language is not just a system but a system which allows its users/speakers to interact with one another. Ogunsiji (2007). This is in agreement with Aito (2004) that language is not realised in abstract. He opines that language is always adaptive and constantly changing. It is realised as the activity in situation and that is why every writing has a specific purpose and are designed for a specific audience. That language and religion are closely related is obvious because language plays a paramount role in propagating various religious beliefs, doctrines, practices etc.

The language of religion is used in sermon delivery, Christian books, religious posters and leaflets, tracts, newsletters and other messages and has been variously studied (Odebunmi (2007), Donovan (1976) etc.). In this work, the messages analysed were sent out by the clerics to their members with the aim that they will perform certain functions in their lives because the production of an utterance is meant to bring about certain changes in the behaviour of the listeners. Being an off shoot of the Orthodox Church, religious language forms an integral part of communication in the Pentecostal church as well. Thus Pentecostal discourse only varies in their extensive use of rhetoric and motivational words. Nonetheless, the spread of Pentecostalism in Nigeria has had a huge influence on almost every Christian church in Nigeria. The idea of register is language use in situation (Dell Hymes, 1972) and the concept of Pentecostal language brings to the fore the issue of register. Longe (1995) believes that appropriateness often leads to the adoption of the notion of restricted language which is characterized partly by the patterns of lexical collocation. For instance, Pentecostals, like some other Christians call one another brother and sister. Some other examples of Pentecostal vocabulary include the following:

- As the Spirit leads

- I'm (was) in the Spirit

- By His grace

\subsection{Language and Change}

The question of whether language might shape the way we think has a great implication on politics, law and religion. The language we speak tends to shape the way we think. Language can have a significant impact on the quality of our interactions. The words we choose while interacting have impact on the people around us. The language of religion is expressed through every facet or environment in which the church exerts its influence. Most of the words and phrases common to the church have their origin in the Bible with meanings unique to those who use them and they are mostly positive confessions that transform the mind-set of the people thereby bringing about certain anticipated changes in behaviour and ways of life.

\section{An Overview of the Theoretical Framework}

This research work will be approached from a pragmatic point of view. This calls for the use of pragmatics. This will assist in the analyses and proper understanding of the content and the context of the selected messages. Pragmatics began with Austin's Speech act theory. This definition of pragmatics according to Odebunmi (2004) captures the essence of speech acts, which is central to any pragmatic study of language. The language we use, and in particular the speech acts we utter are entirely dependent on the context of situation in which such acts are produced. A speech act is never just an 'act of speech', but should be considered in the total situation of activity of which it is a part (Levison 1983), and therefore is a pragmatic act. The speech act theory which postulates that we perform certain acts in our speeches will be adopted for our theoretical framework. However, there are various versions of speech acts theory such as Austin's (1962) conventionbased theory, Searle's (1969) theory of speech acts, Bach and Harnish's (1979) intention and inference-based theory of speech acts which elucidate, people 'don't speak merely to exercise their vocal cords.' They explain that some reason always exists, and this reason is called the communicative presumption: the mutual belief that whenever one person says something to another, the speaker intends to perform an illocutionary act. In other words, a speech act is an utterance that serves a function in communication.

Pragmatics started with Austin's Speech act theory and was further developed and codified by John R. Searle. According to Austin (1962) and as restated by Araki (2018) every utterance a person makes performs speech acts stating an opinion, confirming or denying something, making a prediction or request, giving a piece of advice, making an offer, issuing an order, making a promise, asking a question, thanking somebody, etc. In other words, a speech act is an utterance that serves a function in communication. As stated earlier, there are various versions of speech acts theory but Searle's version is favoured as the model for this study.

\section{Data Analysis}

In relation to the analysis of the data, the emphasis will be on form and function analysis. The five types of illocutionary acts by Searle (1969) namely: Representatives, Directives, Commissives, Expressives and Declarations are found in this work. Commissives dominate the text as they constitute $61.89 \%$ of the entire acts identified because this function in the messages is characterised by predictions, prophecies and promises. This is followed by the representatives in the degree of occurrence because it is used to give background information and explanation with the use of sub acts of stating, informing, reporting, affirming etc. Next are the expressives which occupy $9.45 \%$ of the text acknowledging the goodness of God.Declarations and directives respectively are however at the bottom of the table as illustrated below. 


\begin{tabular}{|cl|cc|c|}
\hline \multicolumn{2}{|c|}{ S/N Pragmatic Acts } & \multicolumn{2}{|c|}{ Distribution } & Sub-acts of General Acts \\
\hline 1 & Commissives & $61.89 \% \quad(190)$ & $\begin{array}{c}\text { promising, predicting, } \\
\text { prophesying }\end{array}$ \\
\hline 2 & Representatives & $21.17 \% \quad(65)$ & $\begin{array}{c}\text { stating, informing, relating, } \\
\text { inferring, affirming }\end{array}$ \\
\hline 3 & Expressives & $09.45 \% \quad(29)$ & acknowledging, assuring \\
\hline 4. & Declarations & $03.91 \% \quad(12)$ & pronouncing \\
\hline 5 & Directives & $03.58 \% \quad(11)$ & asking,prescribing, recommending \\
\hline
\end{tabular}

Table 1: Frequency Distribution of Speech Act Types in the Messages

As discussed earlier, Table 1 in our findings show that there is a preponderance of commissives in the data analysed as it constitutes $61.89 \%$ of the entire acts identified. This is because the clerics make a lot of predictions, prophecies and promises through their messages so as to transform the minds and lives of the people.

Commissives are those kinds of speech acts that speakers use to commit themselves to some future action. They express what the speaker intends according to Yule (1996). The clerics do a lot of predictions, prophecies and promises through their complimentary messages as the spiritual fathers (General Overseer or President as the case may be) of the addressees. A lot of predictions and promises appear in this data with the speakers' intention to encourage the hearer through promises for a better year as will be illustrated from text 2 by Pastor Adeboye of the Redeemed Christian Church of God below.

With your hands untied

And your legs loosed

With blurred vision totally cleared

To great possibilities be you released...

The above example, a commissive from Text 2 by Pastor Adeboye is the New Year message of 2008. Pastor Adeboye opens his greeting to his members with the prayer that great possibilities will open up to them. The illocutionary point is to get the hearer to believe that there is nothing to debar him or her from achieving more in the New Year.

Text 11 by Pastor Emmanuel is another instance and is mainly predictions for 2007.

- This is the year that your life has been waiting for.

- It is your season of Divine rest

- I will remove endless struggles from your life this year.

The above examples are commissives. Here we have the illocutionary function which is to assure the members of the great things ahead of them in the New Year as the pastor predicts and promises above that they will experience God's rest because their struggles will be over and that they will flourish and be successful in the new year.

Representatives are those kinds of speech acts that state what the speaker believes to be the case or not. They are statements of fact, assertions, conclusions, and descriptions. This category commits the speaker to the truth of the proposition stated.

For example in Text 1 taken from Pastor Oyedepo's New Year message of 2007, we take our first example of a representative:

OUR GOD IS AN EVER FORWARD LEADING GOD.

God said to Moses, 'Speak to the children of Israel that they go forward' (Exodus 14:15).

God also speaking in another verse of scripture said 'I am the Lord, I change not' (Malachi 3:6)...

Sentence one in the above text is a representative in which the general overseer is:

- stating the progressive attribute of God

- affirming that God is not static therefore by implication their lives will not be static as they serve God that is ever moving forward and

- by extension that his members will move forward in the new year.

The illocutionary point of the representative is to commit the speaker to believing, to some degree the proposition expressed. That is why the second statement which is a quotation from the Bible is meant to re-affirm this. In the second statement, Pastor Oyedepo is relating this utterance to the first sentence as a confirmation to the earlier one. The deployment of the direct quote enhances persuasion because it creates an avenue for the audience to discover the authoritative source of the message. This reflects a deviation from general greeting cards or complimentary messages which do not need quotes from the Bible to back up its wishes.

Expressives on the other hand are those kinds of speech acts that state what the speaker feels. According to Yule (1996), they express psychological states and can be statements of pleasure, congratulations, greetings, pain, likes, dislikes, joy, or sorrow. etc. This of course relates with major aspects of what compliments are and as such most of these messages comprise speech acts, which express praise, acknowledgement, appreciation, greetings, congratulations, desire for someone's welfare etc. Our first example here is Pastor Adeboye's New Year message of 2007 in Text 3 below:

As trees stood like sentries

The sweet music savouring

Of the choir of birds and windy leaves

We bring you season's greetings

Pastor Adeboye expresses the beauty of nature in his compliments inferring that while nature goes on as usual to compliment the mood of the period he brings 'season's greetings' to his readers. As is customary of expressives, Pastor 
Adeboye's expressions are essentially subjective because expressives according to Mey (2000) expresses an inner state of the speaker. As is also customary to express one's heart felt wishes at this period of the year the cleric, in the last three stanzas of the greeting card pours his heart felt wishes and prayers to the people on them as illustrated below:

Wishing you joy, unspeakable joy

Glory untainted, success unlimited

Health robust, strength and vitality

Peace like a river, ...

These and much much more

Far above all your heart's desires we bring

To you this Christmas and New Year

As a result of the new season, the cleric in the text above, wishes his members and loved one's joy, success, good health, peace and even much more, 'far above all your hearts desires', this Christmas and the New Year.

The sub-acts of acknowledging and assuring are achieved through this message to impact.

Another instance is from Text 7, the New Year message of 2006 by Rev'dYinkaOjo of Grace Family Church below:

I confess God's word that 2006 is my year of THE OVERFLOW

This is my year of Surplus Abundance and Excess of God's goodness

The Lord Anoints my head with oil, my cup overflows

The above speech acts by Rev'dYinkaOjo expresses his psychological state of feeling whereby he expects the confession of the message above to speed up its fulfilment. The purpose is to give the hearer social-psychological confidence in relation to the New Year. This is an expressive. The illocutionary point is that by confessing this message the receiver (the members) admits and acknowledges that it is his year of the overflow and that the Lord anoints his head and his cup runs over. This of course infers an abundance that is in excess and superfluous. Including confessions is not common with other compliments since they do not usually recommend actions to bring about its wishes to the people.

Declarations are those kinds of speech acts that change the world via their utterance such as takes place when christening a baby, firing a worker, declaring peace etc. Below is an example in our corpus from Pastor Oyedepo's New Year message in Text 6 for 2008

Again because we are on the eagle's wings, we are merely being borne by the mother eagle scaling heights without expending energy, scaling heights without stress or strain. I believe this is why we are set to be more than conquerors.

The above example has the illocutionary function of a declarative. The purpose (i.e. illocutionary point of speech act) is affirming the fact that the people are set to become champions (conquerors). On the other hand the statement is a commissive in that it is predicting the fact that the people will be more than conquerors. The illocutionary force here is on 'conquerors' because 'Winners Worldwide shall be the envy of all those around them'. One inference that we make here is related to the hearer-based presupposition of the phrase 'more than conquerors' which is expected to show the degree of the ability to win, to overcome or/and to excel. This can only be decoded by inference by those with the same MCBs according to Bach and Harnish's views already highlighted earlier.

Directives are those kinds of speech acts that speakers use to get someone else to do something. They express what the speaker wants such as commands, orders, requests etc. This category is rather few in the data constituting just 3.58\%. Since these speech acts embody an effort on the part of the speaker to get the hearer to do something, to 'direct' him or her towards some goal (of the speaker's, mostly), the cleric uses this act to get his audience to follow certain directions that will make what they wish to happen for them. This is their illocutionary point. Below is an example by Pastor Oyedepo from text 1 . Therefore they must stay on the word for every change they desire.

- We must engage the word in confronting the challenges of life

- We must apply ourselves to the revealed word of God

- We must put the word to work as a lifestyle.

The illocution is achieved through the word 'must'- a modal that expresses compulsory demand

The above are directives with the aim of getting the addressee to perform certain actions in order to effect change and move higher in the New Year.

\section{Conclusion}

In conclusion, through the speech act theory, we have been able to examine the propositional content of compliments in religious messages and the intention of the speaker to appreciate, assure, exhort and to wish the members better attainment in the New Year which makes them unique from the general complimentary expressions.

Generally, the function that these New Year messages perform in communicating with members of the Pentecostal church and those who share the same MCBs in informing, relating, predicting, promising, declaring and assuring its adherents cannot be underestimated. The application of speech acts theory to these messages provides some insight into the language of religious complimentary messages. Thus, the analysis has drawn attention to the types of speech acts and speech acts functions that characterise these messages which the clerics could use to improve the impact of their messages to encourage and motivate their members in trying times. These speech acts functions in creating impact for change of attitude and gives hope. Thus religious discourse serves as a medium to encourage and motivate people to change their mind set and way of life.

This present study is not in any way exhaustive because it has been limited mainly to the area of speech acts. Moreover, compliments in the area of religious discourse are a relatively new area which needs to be further researched. Thus, this researcher wishes to suggest that further study should be carried out that will be more comprehensive. 


\section{References}

i. Aito. 0. 2004. Graffiti language as an expression of identity in contemporary Nigeria in The Domestication of English in Nigeria.SegunAwonusi and E. A. Babalola Ed. Lagos: University of Lagos Press, pp 567 - 586.

ii. Araki, N. (2018). Speech-Act Theory. Bull. Hiroshima Inst. Tech. Research, 52, 1-5.

iii. Austin, J.L.1962. How To Do Things With Words. New York: Oxford University Press.

iv. Bach K. and Harnish, R. 1979. Linguistic Communication and Speech Acts.Cambridge: MIT Press.

v. Donovan, P. 1976. Religious Language. London: Sheldon Press.

vi. Holmes, J. 1988a. Compliments and compliment responses in NewZealand English, Anthropological Linguistics 28: 485-508.

vii. Holmes, J. 1988b. Paying compliments: A sex-preferential positive politeness strategy. Journal of Pragmatics 12: 445-465.

viii. Hymes, D. 1971. On communicative competence. Philadelphia: University of PennsylvaniaPress.

ix. Levinson, S.C.1983. Pragmatics, Cambridge: Cambridge University Press.

X. Longe, V. U. 1995. Studies in the variety of language. Benin City: Headmark Publishers.

xi. Manes, J., \&Wolfson, N. 1980. The compliment formula. In F. Coulmas (ed.), Conversational routine. The Hague: Mouton, 115-132.

xii. Manes, J. 1983. Compliments: A mirror of cultural values. In N. Wolfson and E.

xiii. .Judd (eds.), Sociolinguistics and language acquisition. Rowley, Mass.: Newbury House, 96-102.

xiv. Mey, J. L. 2004. Pragmatics: An introduction. $2^{\text {nd }}$ ed. Oxford: Blackwell.

xv. Odebunmi, S.A. 2004. Meaning in English: an introduction, Ogbomoso: Critical sphere, LadokeAkintola University of Technology.

xvi. -----.. 2006. Meaning in English: an introduction, Ogbomoso: Critical sphere, LadokeAkintola University of Technology.

xvii. ---------2007. The stylistics of religious electronic advertisements in Nigeriain Odebunmi and Babajide Eds. Style in Religious Communication.Muenchen: LINCOM GmbH

xviii. Ogunsiji, Y. 2007. Some rudiments in the study of conversational discourse in Journal of Communication and English Language Studies. Ede: The departmentOf General Studies, Federal Polytechnic Searle, J. 1969. Speech Acts: An Essay in the Philosophy of Language. Cambridge: University Press.

xix. Yule, G. 1996. Pragmatics. Oxford: Oxford University Press. 